\title{
An Empirical Work on Navigating the Start- Up Ecosystem in Chennai"
}

\author{
Pavanteja, J Pavithra, Anitha.K
}

\begin{abstract}
Enterprise has generally been characterized as the way toward planning, propelling and maintaining another business, which commonly starts as an independent venture, for example, a new business, offering an item, procedure or administration available to be purchased or contract, and the individuals who do as such are called 'business visionaries'. It has been characterized as the "limit and eagerness to create, sort out, and deal with a business adventure alongside any of its dangers so as to make a benefit. While meanings of enterprise normally center around the starting and running of organizations, because of the high dangers engaged with propelling a start-up, a critical extent of organizations need to close, due to an "absence of subsidizing, awful business choices, a monetary emergency or a mix of these" or because of absence of market request
\end{abstract}

\section{INTRODUCTION}

During the 2000s, the meaning of "business enterprise" has been extended to clarify how and why a few people (or groups) distinguish openings, assess them as suitable, and after that choose to misuse them, though others don't, and, thusly, how business visionaries utilize these chances to grow new items or administrations, dispatch new firms or even new ventures and make riches. [1],[3],[5]

Generally, a business visionary has been characterized as "an individual who sorts out and deals with any endeavor, particularly a business, for the most part with impressive activity and risk". Rather than filling in as a representative, a business person maintains a private company and accept all the hazard and reward of a given business adventure, thought, or great or administration offered available to be purchased. The business visionary is ordinarily observed as a business chief and trend-setter of new thoughts and business forms." Entrepreneurs will in general be great at seeing new business openings and they regularly show positive inclinations in their observation (i.e., a predisposition towards finding new potential outcomes and seeing neglected market needs) and a professional hazard taking frame of mind that makes them bound to misuse the chance. [7],[ 9] ,[11]

Revised Manuscript Received on July 22, 2019.

Pavanteja,, Department of MBA,Bharath institute of Higher Education \& Research,Tamilnadu,India Email:pavanteja@gmail.com

J Pavithra, Assistant Professor, Department of MBA,Bharath institute of Higher Education \& Research, Tamilnadu, India Email: pavithralect@yahoo.com

Anitha.K, Department of Civil Engg,Bharath institute of Higher Education \& Research,Tamilnadu,IndiaEmail: anithakrish26@yahoo.co.in

\section{LIMITATIONS OF THE STUDY}

- The start-up ecosystem involves a wider range. The presents study examines it from identified and selected dimensions only. However, it is possible that there may be other factors which might not have been covered in this study.

- Some respondent did not properly respond to the Questionnaire; thus to eliminate this aspect the researcher has also conducted some personal interviews.

- It was a bit difficult to get the respond back on time as people where busy with their business.

- As people where limited in numbers there may be chances that information provided by them can be false.

Table : 1 Motivational Factors

\begin{tabular}{|l|l|l|}
\hline OPTIONS & $\begin{array}{l}\text { NO. OF } \\
\text { RESPONDENT }\end{array}$ & $\begin{array}{l}\text { PERCENTAGE } \\
(\%)\end{array}$ \\
\hline PASSION & 20 & 20 \\
\hline $\begin{array}{l}\text { TO EARN } \\
\text { MORE }\end{array}$ & 24 & 24 \\
\hline $\begin{array}{l}\text { BE MY } \\
\text { OWN BOSS }\end{array}$ & 21 & 21 \\
\hline $\begin{array}{l}\text { FAMILY } \\
\text { BUSINESS }\end{array}$ & 16 & 16 \\
\hline $\begin{array}{l}\text { FLEXIBLE } \\
\text { SCHEDULE }\end{array}$ & 12 & 12 \\
\hline OTHERS & 7 & 7 \\
\hline TOTAL & $\mathbf{1 0 0}$ & $\mathbf{1 0 0}$ \\
\hline
\end{tabular}

\section{INFERENCE:}

The above table shows that, $20 \%$ people doing business due to their passion and $7 \%$ due business to other reasons GRAPH : 1

\section{MOTIVATIONAL FACTORS}

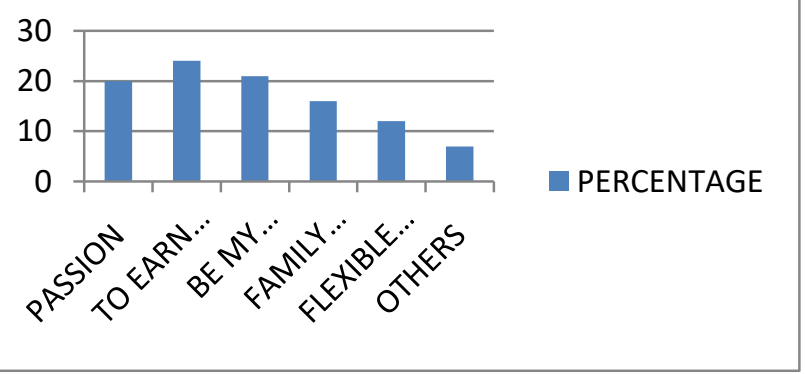


TABLE : 2 OPINION ABOUT INSPIRATION

\begin{tabular}{|c|c|c|}
\hline OPIIOIS & IO, OF RESPOODESTIT & PERCENTIGE (y) \\
\hline FAVIIYREEATIIVS & 26 & 26 \\
\hline \begin{tabular}{|ll} 
BUSNIESS & TICOONS \\
BIOGRAPHIISS & \\
\end{tabular} & 30 & 30 \\
\hline $\begin{array}{ll}\text { MOOTINATONS } \\
\text { OTHERS }\end{array}$ & 29 & 29 \\
\hline OIHERS & 15 & 15 \\
\hline TOTAL & 100 & 100 \\
\hline
\end{tabular}

INFERENCE:

In the above table, $26 \%$ respondent said that they are inspired by families/relatives and $15 \%$ respondent said that it is because of other various reasons. [8],[10],[12]

GRAPH : 2

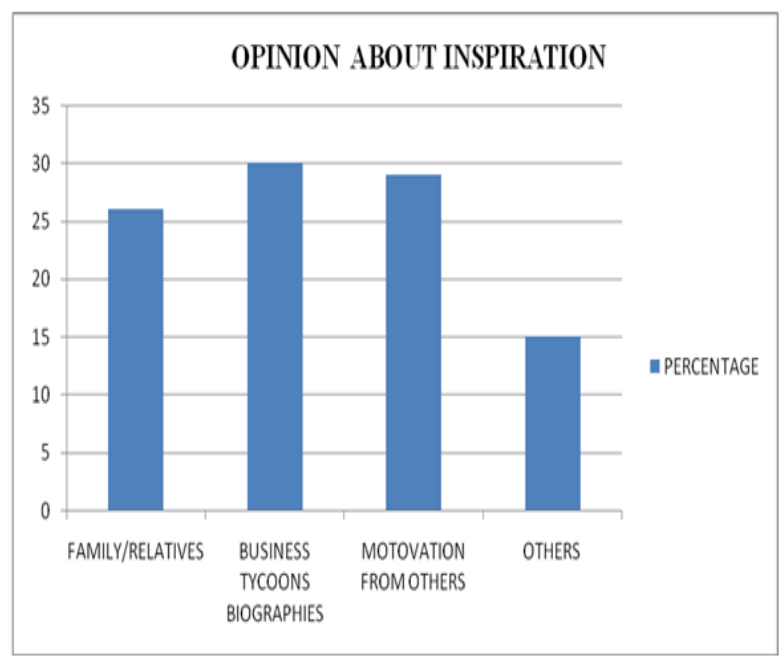

TABLE : 3 WORK IN CORPORATE COMPANIES

\begin{tabular}{|c|c|c|}
\hline OPMOYS & 10, OF RESOONDEVT & PERCETIAGE (YO) \\
\hline$\overline{V E S}$ & 35 & 35 \\
\hline 10 & 65 & 65 \\
\hline TOILL & IIII & 100 \\
\hline
\end{tabular}

\section{INFERENCE:}

In the above table $35 \%$ people said that they have worked in companies and $65 \%$ people said that they haven't worked earlier in companies

GRAPH : 3

\section{WORK IN CORPORATE COMPANIES}

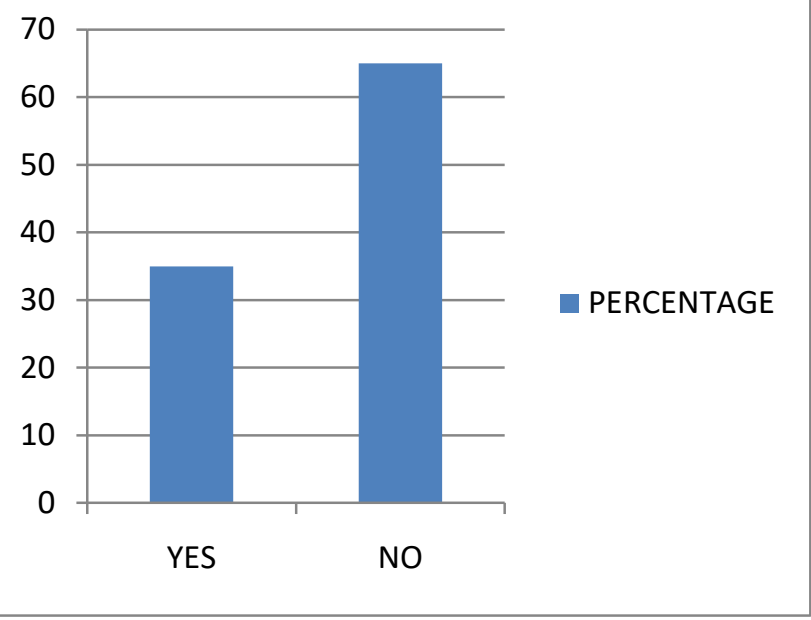

Table : 4 Reason Behind Leaving The Company

\begin{tabular}{|c|c|c|}
\hline OPITOYS & I0, OF RESPONDENTI & PERCENTAGE (\%) \\
\hline SSTERTOR PRESSSTRE & 6 & 6 \\
\hline \begin{tabular}{|l|} 
TORR ENVIROMNENT \\
\end{tabular} & 13 & 13 \\
\hline SALARY, NOT SATISPED & 11 & 11 \\
\hline OTHERS & j & 5 \\
\hline TOTLL & 35 & 35 \\
\hline
\end{tabular}

\section{INFERENCE:}

In the above table, $6 \%$ respondent said that the reason behind leaving the company is superior pressure and 5\% respondent said that they left the company because of various other reasons. [13], [15], ,17]

\section{RESULTS}

- Most of the respondent said that they got motivated due to passion and few of the respondents got motivated due to various other reasons.

- $30 \%$ respondent got inspiration from business tycoons biographies and $15 \%$ respondent got inspired from other reasons.

- Only few respondents said that they have worked in corporate companies and many of respondents said that they haven't work.

- $13 \%$ respondent left their company due to work environment and 5\% respondent said that they left their company due to other reasons.

- Almost of half of the respondents said that they don't regret about leaving the company and only less number of respondents said that have any opinion about it. 
- $51 \%$ respondent said that they think their business as success and $8 \%$ respondent said that they don't think their business as success.

- Most of the respondents said that they are highly satisfied and pursuing their passion whereas small number of respondents said that they are highly dissatisfied and not pursuing their passion. [14],[ 16], [18]

- $24 \%$ respondent said that they are managing their business without much experience and $6 \%$ said that they are not managing their business without much experience. [31],[33]

- Many of the respondents said that they faced problem due to lack of experience while starting the business and few respondents said that they faced problem due to time management. [19],[21],[23]

- $31 \%$ respondent said that due to investment they faced problem after starting business and $2 \%$ due to strain/learning.

- Nearly half of the respondents said that they started business after 1-3years of experience and few respondents said that they started business after 5years of experience. - $32 \%$ respondent said that they have worked in companies and $68 \%$ respondent said that they haven't work in companies. [25],[27],[29]

- Many of the respondents said that they disagreed and won't switch to job and only few respondents highly agreed that they will switch to jobs if they paid more.

- $30 \%$ respondent said that sales knowledge is required to run a business and $6 \%$ respondent said that delegation of work skill is needed to run a business.

- Half of the respondents said that they are neutral for education important for business and only less number of respondent highly disagree that education is important to run a business.

- $61 \%$ respondent thinks that right age to start business is between 26-35 years and 1\% thinks that right age to start business is $46-50$ years

\section{DISCUSSION}

As suggestion my point of view towards this topic is that as India is getting digitalized and more employment is needed, so start-ups can play a very important role for the employees, for the entrepreneur and even for the country. But I believe an entrepreneur should get few years of experience into the company as it will help them, their employees and their own business too.

Skills and Talents should be utilized properly so that it can help business to grow and also sustain in the market. Few respondents said that they don't feel that education is important, but I suggest that education is important is every aspect of life.

\section{CONCLUSION}

Nowadays, young generation are opting for start-ups rather than going for companies to work, in my project I have shown that why youths are going for their own business and what is the relationship between start-ups business and unemployment.

Around 20\% respondent said that they choose to do business because they want to earn more. $30 \%$ respondent said that they got inspiration from business tycoons and their biographies. Few of them agreed that they have already worked in corporate companies and due to reasons like superior pressure, work environment and less salary they left the organization. Around $31 \%$ respondent said that they are highly satisfied as they are continuing their passion through business. $17 \%$ respondent said that while starting the business they faced problems like loan issues, family support, lack of knowledge, etc. [26],[28],[30]

\section{REFERENCES}

1) BharthVajan R., Ramachandran S.,Psychographic dimensions of training,2016,International Journal of Pharmacy and Technology,V-8,I-4,P-23727-23729

2) Balakrishnan P., Bharthvajan R.,A study on human resource planning in hospitals in Chennai City,2014,International Journal of Applied Engineering Research,V-9,I-22,P-7503-7507

3) Priyadarsini P., Bharthvajan R.,Role of emotional intelligence training programme in reducing the stress of the nurses,2014,International Journal of Applied Engineering Research,V-9,I-22,P-7411-7421

4) Kerinab Beenu G., Bharthvajan R.,Empirical analysis on the cosmetic buying behavior of young women in South India,2014,International Journal of Applied Engineering Research,V-9,I-22,P-7361-7366

5) Balakrishnan P., Bharthvajan R.,Whistling in the wind,2014,International Journal of Applied Engineering Research,V-9,I-22,P-7586-7593

6) Krishnan B., Peter M.,Health hazards of Indian Bpo employee-an alarming issue,2014,International Journal of Applied Engineering Research,V-9,I-22,P-7336-7341

7) Kerinab Beenu G.H., Peter M.,Role of insurance in economic development,2014,International Journal of Applied Engineering Research,V-9,I-22,P-7532-7539

8) Balakrishnan P., Peter M., Priyadarsini P.,Efficiency of safety measures for wellbeing of employees in manufacturing industry,2014,International Journal of Applied Engineering Research,V-9,I-22,P-7376-7382

9) Anbarasi M., Praveen Kumar S.,Online sales promotions of herbal products and its effectiveness towards tanisha.com,2019, Indian Journal of Public Health Research and Development,V-10,I-1,P-195-200

10) Anbarasi M., Praveen Kumar S.,Various online marketing and promotions strategies to improve the validation towards the organic products in the pharmaceutical sectors,2019,Indian Journal of Public Health Research and Development, V-10,I-1,P-263-269

11) Loganathan R., Praveen Kumar S.,Grievance handling a key factor for solving issues of employees in an organization,2014,International Journal of Applied Engineering Research,V-9,I-22,P-7483-7491

12) Loganathan R., Praveen Kumar S.,Study on preference of private label brands in super and Hypermarkets,2014,International Journal of Applied Engineering Research,V-9,I-22,P-7327-7335

13) Smitha M., Praveen Kumar S.,Understanding stress and its managementamong the nurses in Chennai city,2014,International Journal of Applied Engineering Research,V-9,I-22,P-7560-7565

14) Kerinab Beenu G.H., Praveen Kumar S.,A study on the investment behavior of Chennai investors in mutual fund schemes,2014,International Journal of Applied Engineering Research,V-9,I-22,P-7520-7525

15) Loganathan R., Praveen Kumar S.,Retention strategies key for organizational productivity,2014,International Journal of Applied Engineering Research,V-9,I-22,P-7443-7447

16) Pavithra J., Ganesan M., Brindha G.,State wise analysis of microfinance sector in India,2016, International Journal of Pharmacy and Technology,V-8,I-4,P-23417-23432

17) Pavithra J., Ganesan M.,A comparative study on microfinance in India and abroad,2016,International Journal of Applied Business and Economic Research,V-14,I-8,P-5471-5476

18) Pavithra J., Ganesan M.,A study on awareness and impact of 
micro-financial schemes,2016,International Journal of Applied Business and Economic Research,V-14,I-8,P-5449-5460

19) Senthilmurugan P., Pavithra J.,Consumer preference towards organised retailing with reference to Big Bazaar,2014,International Journal of Applied Engineering Research,V-9,I-22,P-7469-7475

20) Senthilmurugan P., Pavithra J.,Implication of social media marketing in growing healthcare industry,2014,International Journal of Applied Engineering Research,V-9,I-22,P-7448-7456

21) Loganathan R., Pavithra J.,Consumer perception towards private label brand over other brands in super markets and hypermarkets,2014,International Journal of Applied Engineering Research,V-9,I-22,P-7355-7360

22) Kerinab Beenu G., Pavithra J.,Tradeâ€"off between liquidity and profitability in logistics industry,2014,International Journal of Applied Engineering Research,V-9,I-22,P-7398-7401

23) Kerinab Beenu G., Pavithra J.,A study on the prospective consumerâ€ $€^{\mathrm{TM}_{S}}$ perception towards utility cars in Chennai city,2014,International Journal of Applied Engineering Research,V-9,I-22,P-7526-7531

24) Pavithra J., Dilli Babu P., Ambuli T.V.,A study on budgetary control at Maruti Service Masters, Chennai,2014,International Journal of Applied Business and Economic Research,V-12,I-2,P-151-161

25) Pavithra J., Dilli Babu P., Ambuli T.V.,A study on customer satisfaction of retro Garments Pvt Ltd, Chennai,2014,International Journal of Applied Business and Economic Research,V-12,I-2,P-381-391

26) Kerinab Beenu G.H., Pavithra J., Senthilmurugan P.,A study on the influence of promotional activities for TATA ARIA among consumers in Chennai,2014,International Journal of Applied Engineering Research,V-9,I-22,P-7572-7578

27) Vijayaragavan S.P.,An investigative expert that's general FBG sensors,International Journal of Mechanical Engineering and Technology, V-8,I-8,PP-1500-1505,Y-2017

28) Vijayaragavan S.P.,Equalization routing protocol for $\mathrm{Wi}-\mathrm{Fi}$ sensor strategy,International Journal of Mechanical Engineering and Technology,V-8,I-8,PP-1662-1666,Y-2017

29) Karthik B., Kiran Kumar T.V.U., Vijayaragavan P., Bharath Kumaran E.,Design of a digital PLL using 0.35 $\hat{\mathrm{I}}^{1 / 4 \mathrm{~m}}$ CMOS technology,Middle East Journal of Scientific Research,V-18,I-12,PP-1803-1806,Y-2013

30) Kanniga E., Selvaramarathnam K., Sundararajan M.,Kandigital bike operating system,Middle - East Journal of Scientific Research,V

31) Jasmin M., Vigneshwaran T., Beulah Hemalatha S.,Design of power aware on chip embedded memory based FSM encoding in FPGA,International Journal of Applied Engineering Research,V-10,I-2,PP-4487-4496,Y-2015

32) Jasmin M.,Optimization techniques for low power VLSI circuits,Middle East Journal of Scientific Research,V-20,I-9,PP-1082-1087,Y-2014

33) Jasmin M., Vigneswaran T.,Fuzzy controller for error control of on - Chip communication,2017 International Conference on Algorithms, Methodology, Models and Applications in Emerging Technologies, ICAMMAET 2017,V-2017-January,I-,PP-1-5,Y-2017

\section{AUTHORS PROFILE}

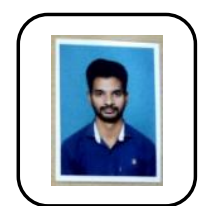

Pavanteja,, Department of MBA,Bharath institute of Higher Education \& Research,Tamilnadu,India Email:pavanteja@gmail.com

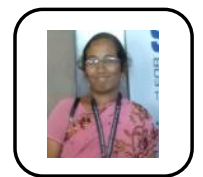

J Pavithra, Assistant

Professor, Department of MBA,Bharath institute of Higher Education \& Research,Tamilnadu,India

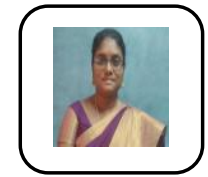

Anitha.K, Assistant ProfessorDepartment of Civil,Bharath institute of Higher Education \& Research,Tamilnadu,India 